\title{
Spirorchiids (Digenea: Spirorchiidae) infecting a Hawksbill sea turtle Eretmochelys imbricata (Linnaeus 1758) from Brazil
}

[Spirorchiids (Digenea: Spirorchiidae) infectando uma tartaruga marinha de pente Eretmochelys imbricata (Linnaeus 1758) no Brasil]

\author{
M.R. Werneck ${ }^{1}$, B.M.G. Gallo ${ }^{1}$, R.J. Silva ${ }^{2}$ \\ ${ }^{1}$ Fundação Pró-Tamar \\ Rua Antônio Athanazio, 273 \\ 11680-000 - Ubatuba, SP \\ ${ }^{2}$ Departamento de Parasitologia - IB-UNESP - Botucatu, SP
}

\begin{abstract}
The occurrence of Amphiorchis caborojoensis Fischthal \& Acholonu 1976 and Carettacola stunkardi Martin \& Bamberger 1952 in a young specimen of Hawksbill sea turtle Eretmochelys imbricata Linnaeus 1758 in Brazil was reported. Five A. caborojoensis trematodes were found in the small intestine $(\mathrm{n}=2)$ and liver ( $\mathrm{n}=3$ ), and two adult $C$. stunkardi specimens were collected from body wash. This is the first report of parasites of E. imbricata in Brazilian waters and Southwestern Atlantic Ocean and the second report of members of the Spirorchiidae family in that region. In addition, E. imbricata is a new host recorded for $C$. stunkardi.
\end{abstract}

Keywords: sea turtle, helminth infection, Amphiorchis caborojoensis, Carettacola stunkardi

\section{RESUMO}

Relata-se a ocorrência de Amphiorchis caborojoensis Fischthal \& Acholonu 1976 e Carettacola stunkardi Martin e Bamberger 1952, em um exemplar juvenil de tartaruga marinha de pente Eretmochelys imbricata Linnaeus 1758 no Brasil. Foram coletados cinco trematódeos da espécie A. caborojoensis, dois no intestino delgado e três no fígado e dois exemplares adultos de C. stunkardi no lavado corporal. Destes apenas a espécie A. caborojoensis já tinha sido relatada como parasita dessa espécie de quelonio marinho. Esta é a primeira descrição de parasitas em E. imbricata em águas brasileiras e na área do Atlântico Sul Ocidental, e o segundo relato de membros da familia Spirorchiidae na mesma região.

Palavras-chave: tartaruga marinha, helmintofauna, Amphiorchis caborojoensis, Carettacola stunkardi

\section{INTRODUCTION}

Ten of the 19 genera of the family Spirorchiidae Stunkard 1921 include trematodes of sea turtles (Platt, 2002). Most of them were found in Chelonia mydas Linnaeus 1758 and Caretta caretta Linnaeus 1758.

Few reports about helminth infection in Eretmochelys imbricata Linnaeus 1758 have been published. Only seven trematode species of the family Spirorchiidae, including the genera
Amphiorchis Price 1933, Hapalotrema Looss 1899, and Learedius Price 1934, were reported in E. imbricata, all from the Pacific, Indian and North Atlantic Oceans (Smith, 1997). The only species of the Spirorchidae family observed in the Brazilian coast was L. learedi Price 1934, found in C. mydas (Werneck et al., 2006). No parasites have been reported in E. imbricata in this same region (Travassos et al., 1969). In this work, the occurrence of Spirorchids specimens in a young E. imbricata was reported in Brazil.

Recebido em 20 de junho de 2007

Aceito em 31 de março de 2008

E-mail: max@tamar.org.br 


\section{CASE DESCRIPTION}

In October 2005, the Center for Rehabilitation of Sea Turtles of the TAMAR-ICMBio project received a turtle of the species $E$. imbricata from Ubatuba region, North of São Paulo State, Brazil. The specimen was $43 \mathrm{~cm}$ carpace length and weighed $7.5 \mathrm{~kg}$.

Necropsy was performed according to Wyneken (2001). The celomatic cavity was opened, the gastrointestinal tract was separately analyzed (esophagus, stomach, small intestine, and large intestine), and heart, spleen, liver, mesenterium, lungs, kidneys, and "body wash" were collected and processed as reported by Werneck et al. (2006). Examination showed that the animal was a young female, with lung lesions (lung emphysema and edema) suggestive of drowning. Several 1-2mm diameter dark brown nodules were observed in the mesenterium, pancreas, salt gland, and serosal surface of the small intestine.

The helminths were fixed in AFA solution, stained with chloridric carmine and analyzed by image analysis computer system ${ }^{1}$. Morphometrical values (in micrometers) are shown as mean and range (minimum and maximum values). After identification, the specimens were deposited in the Coleção Helmintológica do Instituto de Biociências, Unesp, Botucatu, São Paulo State, Brazil.

\section{RESULTS AND DISCUSSION}

After the parasitological examination, the following helminthes were identified:

Trematoda - Family: Spirorchiidae Stunkard 1921

1. Amphiorchis caborojoensis Fischthal \& Acholonu 1976

Host: Eretmochelys imbricata Linnaeus 1758

Locality and collection date: Ubatuba city, Cedro beach (23 $27^{\prime} 30,4^{\prime} \mathrm{S}$; $\left.45^{\circ} 01^{\prime} 47^{\prime} \mathrm{W}\right)$, North Coast of São Paulo State, Brazil, on October $1^{\text {st }}$, 2005;

Sites of infection: small intestine $(\mathrm{n}=2)$ and liver $(n=3)$;

Intensity of infection: One host with five specimens;
Voucher specimens deposited: CHIBB numbers 1392 and 1406;

Measurements $(\mathrm{n}=5)$ : body $5717.6(5550.6-5883.3)$ by 1006.4 (939.5-1063.8); oral sucker 217.8 (211.6-220.7) x 201.4 (196-209.8); ventral sucker $285.3(5276.7-294) \times 228.4$ (212.4-300); esophagus 1717.1 (1707.3-1958.9) x 197.3 (176-226.6); distances between testes $771.6 \quad(710-833.3)$; anterior testis $775.1(680.8-820) \times 684.5$ (585.7751.3); posterior testis $633.6(547-766) \times 576.9$ (495.4-667.4); from anterior testis to ventral sucker 841.3 (760-955.3); from anterior testis to the anterior end 3358.9 (3185.5-3558.6); from the posterior testis to the posterior end 143 (103.3184.3) external seminal vesicle 209.2 (188.6243.1); cirrus sac 323.9 (324.4-323.9); ovary 460.5 (359.6-516.2) x 447.6 (400.6-494.6); number of lobes of ovary five; from ovary to the anterior end 4374.4 (4223.6-4593.3); from ovary to the posterior end 856.2 (835.2-993.5); eggs 0.322 $(0.247-0.382)$ with filaments $\mathrm{x} 0.056(0.0476-$ $0.0645)$

Five species are recognized in the genus Amphiorchis: A. amphiorchis Price 1934; A. lateralis Oguro 1938; A. indicus Mehrotra, 1973; A. caborojoensis Fischthal \& Acholonu 1976; and $A$. indicum Simha \& Chattopadhyaya, 1980. All these species have been reported in animals from the Pacific, Indian, and North Atlantic Oceans (Smith, 1997).

Amphiorchis amphirochis has been reported as parasites of $C$. mydas (Price, 1934) and $E$. imbricata (Fischthal and Acholonu, 1976), whereas A. lateralis (Oguro, 1938), A. indicus (Gupta and Mehrotra, 1981), A. indicum (Simha and Chattopadhyaya 1980; Smith, 1997), and $A$. caborojoensis (Fischtal and Acholonu, 1976; Dayer et al., 1995) were only found in $E$. imbricata. There are no reports, however, of these parasites in the Brazilian coast or Occidental South Atlantic. Similarly, there are no reports about the existence of parasites in the $E$. imbricata specimens found in this region (Travassos et al., 1969).

Morphometric data showed larger proportions than those found in other studies, which could be due to individual variability within the species and did not interfere on their identification.

${ }^{1}$ QWin Lite 3.1, Leica, Germany. 
Eggs were not found in the parasite uterus; but at necropsy several $1-2 \mathrm{~mm}$ diameter dark nodules were observed on the serosal surface of the small intestine, mesenterium, pancreas, brain, and salt gland of the turtle. The macroscopic aspect of the lesions was similar to that reported by Gordon et al. (1998) in C. mydas. Lesions were dissected, and under a stereomicroscope, clusters of ellipsoid eggs with only one filament in each extremity were observed, as previously reported for A. caborojoensis specimens (Fischthal and Acholonu, 1976).

It is important to notice that the occurrence of $A$. caborojoensis in E. imbricata has only been reported in the Caribbean region, in Porto Rico (Fischtal and Acholonu, 1976; Dayer et al., 1995). The present work represents the third report on this parasitism, and the first one observed out of the Caribbean region.

Trematoda - Family: Spirorchiidae Stunkard 1921

2. Carettacola stunkardi Martin and Bamberger 1952

(Syn. Haemoxenicon stunkardi)

Host: Eretmochelys imbricata Linnaeus 1758

Locality and collection date: Ubatuba city, Cedro beach $\left(23^{\circ} 27^{\prime} 30,4^{\prime} \mathrm{S}\right.$; $\left.45^{\circ} 01^{\prime} 47^{\prime} \mathrm{W}\right)$, North Coast of São Paulo State- Brazil, on October $1^{\text {st }}, 2005$;

Site of infection: Body wash;

Intensity of infection: one host with two specimens;

Voucher specimens deposited: CHIBB number 1395

Measurements $(\mathrm{n}=1)$ : body 6.504 by 0.469 ; oral sucker 0.100 x 0.091 ; ventral sucker 0.248 x 0.257 ; ratio length oral sucker:ventral sucker 0.4 ; ratio width oral sucker:ventral sucker 0.3 ; esophagus $0.727 \times 0.096$; number of testes 39 ; testis (mean) $0.212 \times 0.154$; cirrus sac $0.223 \times 0.159$; seminal vesicle $0.148 \times 0.152$; ovary $0.333 \times 0.241$; seminal receptacle $0.133 \times 0.082$; vitteline reservoir $0.175 \mathrm{x}$ 0.242 ; no eggs observed.

Manter and Larson (1950) classified in the genus Carettacola a new parasite, named Carettacola bipora Manter and Larson 1950, found in blood vessels of a sea turtle of the species $C$. caretta. Soon after that, Martin and Bamberger (1952) erroneously identified parasites collected from $C$. mydas, and determined a new genus named Haemoxenicon to include the species $H$. stunkardi and $H$. chelonenecon. Caballero et al. (1955), studying parasites from Mexican sea turtles, reexamined these species and determined that $H$. stunkardi and $H$. chelonenecon are synonymous. Dailey et al. (1991) evaluated specimens collected in Hawaii and organized the genus Carettacola, presenting an identification key that included three species, $C$. bipora, $C$. stunkardi, and C. hawaiiensis Dailey, Fast and Balazs 1991.

The present work used the classification system proposed by Dailey et al. (1991) that emphasizes as species-specific characteristics the position of the vitellaria in relation to the cecum and the position of the opening of the Laurer's canal. The specimens analyzed in this study showed the vitellaria more dorsal in relation to the cecal branches, and absence of a lateral opening of the Laurer's canal, as described for C. stunkardi in that classification.

Only C. mydas has been reported as a host for $C$. stunkardi, in the North Pacific region (Martin and Bamberger, 1952) and Panama (Caballero et al., 1955). This study shows E. imbricata as a new host for this parasite.

Morphometric data observed in the present work showed larger dimensions than those previously reported. However, they did not interfere in the identification of the specimens and are possibly due to individual variation within the species.

Only eggs of $A$. caborojoensis were found in host tissues, which could reflect less maturity of the $C$. stunkardi specimens.

Some specimens were collected from the digestive tract or from body wash, similar to the study by Price (1934). It is possible that the parasites were released from the circulatory system when the host was eviscerated.

Mixed infection by spirorchids has not been previously reported in this host, but this type of association has already been observed in $C$. mydas (Rand and Wiles, 1985, Glazebrook et al., 1989; Dailey et al., 1992; Raidal et al., 1998).

The present study is the first report of these species in the Brazilian Coast and Southwester South Atlantic Region, representing an important information about the helmithofauna in this 
region and enlarging the previously known geographical distribution of the species. In addition, this study shows $E$. imbricata as a new host for C. stunkardi.

\section{AKNOWLEDGEMENTS}

Projeto TAMAR is affiliated with ICMBio, comanaged by the Fundação Pró-TAMAR, and officially sponsored by PETROBRAS. The authors wish to express their thanks to Paula Baldassin and Cecília Baptistotte for critical reading and suggestions to improve the quality of the manuscript. We would like to thank the Fundação de Amparo à Pesquisa do Estado de São Paulo - FAPESP (Proc. 07/59504-7) for the financial support.

\section{REFERENCES}

CABALLERO, E.C.; ZERECERO, M.C.D.; GROCOTT, R.G. Helmintos de la República de Panamá XV. Trematódeos de Chelone mydas (L.), tortuga marina comestible del Oceano Pacífico del Norte $2^{\circ}$. Parte. $A n$. Inst. Biol. Mex., v.26, p.149-191, 1955.

DAILEY, M.D.; FAST, M.L.; BALAZS, G.H. Carettacola hawaiiensis N. SP. (Trematoda: Spirorchiidae) from the green turtle, Chelonia mydas, in Hawaii. J. Parasitol., v.77, p.906-909, 1991.

DAILEY, M.D.; FAST, M.L.; BALAZS, G.H. A survey of the trematoda (Platyhelminths: Digenea) parasitic in green turtles, Chelonia mydas from Hawaii. Bull. South Calif. Acad. Sci., v.91, p.84-91, 1992.

DAYER, W.G.; WILLIAMS, E.H.; BUNKLEYWILLIAMS, L. Some Digeneas (Trematoda) of the Atlantic Hawksbill turtle, Eretmochelys imbricata imbricata (Testudines: Cheloniidae) from Puerto Rico. $J$. Helminthol. Soc. Washington, v.62, p.13-17, 1995.

FISCHTHAL, J.H.; ACHOLONU, A.D. Some digenetic trematodes from Atlantic Hawksbill turtle Eretmochelys imbricata imbricata (L.) from Puerto Rico. J Helminthol Soc. Washington, v.43, p.174-185, 1976.

GORDON, A.N.; KELLY, W.R.; CRIBB, T.H. Lesions caused by cardiovascular flukes (Digenea: Spirorchidae) in stranded green turtles (Chelonia mydas). Vet. Pathol., v.35, p.21-30, 1998.

GLAZEBROOK, J.S.; CAMPBELL, R.S.F.; BLAIR, D. Studies on cardiovascular flukes (Digenea: Spirorchiidae) infections in sea turtles from the Great Barrier Reef, Quensland, Australia. J. Comp. Pathol., v.101, p.231-250, 1989.

GUPTA, N.K.; MEHROTRA, V. On two blood flukes (trematoda) of the Family Spiorchiidae Stunkard, 1921 from Indian marine turtles. Acta Parasitol. Pol., v.28, p.11-20, 1981.

MANTER, H.W.; LARSON, M. Two new blood flukes from marine turtle, Caretta caretta. J. Parasitol., v.36, p.595-599, 1950.

MARTIN, W.E.; BAMBERGER, J.W. New blood flukes (Trematoda: Spirochiidae) from the marine turtle, Chelonia mydas (L.). J. Parasitol., v.38, p.105-110, 1952.

OGURO, Y. A new blood flukes, Amphiorchis lateralis nov.sp. (Spirorchiidae) found in a marine turtle in Japan. J. Sci. Hiroshima Univ., v.6, p.1-4, 1938.

PLATT, T.R. Family spirorchiidae Stunkard. In: GIBSON, D.I.; JONES. A.; BRAY, R.A. (Eds). Keys to the Trematoda. London: CABI Publishing, 2002. p.453467.

PRICE, E.W. New genera and species of blood flukes from a marine turtle, with key to the genera of the family Spirorchiidae. J. Wash. Acad. Sci., v.24, p.132-141, 1934.

RAIDAL, S.R.; OHARA, M.; HOBBS, R.P. et al. Gramnegative bacterial infections and cardiovascular parasitism in green sea turtles (Chelonia mydas) Austr. Vet. J., v.76, p.415-417, 1998.

RAND, T.G.; WILES, M. Histopathology of infctions by Learedius learedi Price, 1934 and Neospirorchis schistosomatoides Price, 1934 (Digenea: Spirorchiidae) in wild green turtles, Chelonia mydas L., from Bermuda. $J$. Wildl. Dis., v.21, p.461-463, 1985.

SIMHA, S.S.; CHATTOPADHYAYA, D.R. Studies on the trematode parasites of reptiles of India. Contributions to the knowledge of blood flukes from the marine turtles, from the Gulf of Manar [sic], South India. (1978). J. Zool. Soc. India, v.30, p.69-82, 1980.

SMITH, J.W. The blood flukes of cold-blood vertebrates. Helminthol. Abstr., v.66, p.255-294, 1997.

TRAVASSOS, L.; FREITAS, J.F.T.; KOHN, A. Trematódeos do Brasil. Mem. Inst. Oswaldo Cruz, v.67, p.1-886, 1969.

WERNECK, M.R.; BECKER, J.H.; GALLO, B.G.; SILVA, R.J. Learedius learedi Price 1934 (Digenea, Spirorchiidae) in Chelonia mydas Linnaeus 1758 (Testudines, Chelonidae) in Brazil: case report. Arq. Bras. Med. Vet. Zootec., v.58, p.550-555, 2006.

WYNEKEN, J. The anatomy of sea turtle. Silver Springs: US Departament of Commerce NOAA, 2001. 172p. (Technical Memorandum NMFS-SEFSC-470). 